\title{
Data report: concentration and sulfur isotope composition of iron monosulfide and pyrite from sediment collected during IODP Expedition $316^{1}$
}

\author{
Natascha Riedinger ${ }^{2}$ and Benjamin Brunner ${ }^{3,4}$
}

\section{Chapter contents}

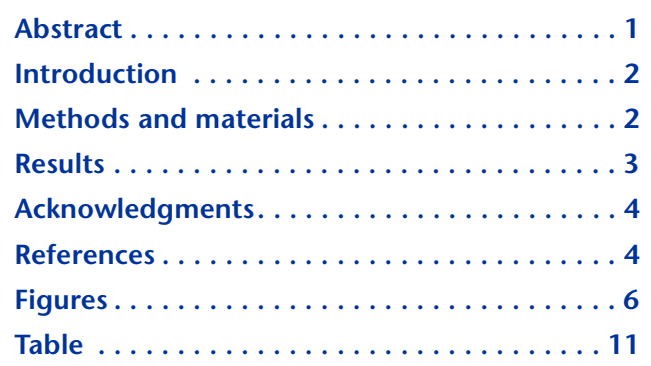

${ }^{1}$ Riedinger, N., and Brunner, B., 2014. Data report: concentration and sulfur isotope composition of iron monosulfide and pyrite from sediments collected during IODP Expedition 316. In Kinoshita, M., Tobin, H., Ashi, J., Kimura, G., Lallemant, S., Screaton, E.J., Curewitz, D., Masago, H., Moe, K.T., and the Expedition 314/315/316 Scientists, Proc. IODP, 314/315/316: Washington, DC (Integrated Ocean Drilling Program Management International, Inc.). doi:10.2204/iodp.proc.314315316.223.2014 2Department of Earth Sciences, University of California, Riverside CA 92521, USA. natascha.riedinger@ucr.edu

${ }^{3}$ Center for Geomicrobiology, Department of Bioscience, Aarhus University, 8000 Aarhus C, Denmark.

${ }^{4}$ Department of Biogeochemistry, Max Planck Institute for Marine Microbiology, 28359 Bremen, Germany.

\begin{abstract}
In this report, we give the concentration and sulfur isotope composition of iron monosulfide and pyrite in samples recovered during Integrated Ocean Drilling Program Expedition 316 to the Nankai Trough, Japan. We studied the impact of complex tectonic activity in this depositional system on the precipitation and occurrence of iron sulfide minerals and their isotopic composition by analyzing samples from sediment cores taken at the megasplay fault and frontal thrust.

The dominating iron sulfide species is pyrite with concentrations up to $2 \mathrm{wt} \%$ (median $=3325 \mathrm{ppm}$, average $=4480 \mathrm{ppm}$, and minimum $=20 \mathrm{ppm} ; n=197)$. The sulfur isotope composition of pyrite covers a range from -49 to $+47 \%$ (median $=-17 \%$ and average $=-18 \% ; n=117)$. Strongly negative sulfur isotope compositions, which are typical for open-system conditions where sulfate enriched in ${ }^{34} \mathrm{~S}$ can be exchanged with seawater, tend to be associated with relatively low pyrite concentrations. Strong enrichments in ${ }^{34} \mathrm{~S}$ in pyrite tend to be associated with high pyrite content. With one exception, boundaries between sedimentary units are associated with low pyrite content and strongly negative sulfur isotope composition. This could indicate that these boundaries may have acted as conduits for sulfate exchange between pore water and seawater for most of the time since the deposition of the sediment, preventing establishment of closed-system conditions. In contrast, within undisturbed sediment packages closed-system conditions promoted a high degree of sulfate consumption and concomitant incorporation of sulfide enriched in ${ }^{34} \mathrm{~S}$ into the pyrite fraction. In some cases, sulfate drawdown was quantitative, leading to terminal degradation of organic matter by methanogenesis and to the installation of sulfate-methane transitions. Where such transitions persisted over a substantial period of time, pyrite strongly enriched in ${ }^{34} \mathrm{~S}$ could accumulate. Iron monosulfide concentrations are generally low $($ median $=1.5 \mathrm{ppm}$, average $=44.8 \mathrm{ppm}$, and maximum $=1952.7$ ppm; $n=195$ ). Slightly elevated concentrations appear to be tied to specific sediment units, suggesting that their inventory of reactive iron species allows for an ongoing interplay with the sulfur cycle and thus sustaining the presence of these mineral phases.
\end{abstract}




\section{Introduction}

As part of the multiphase-multiyear Nankai Trough Seismogenic Zone Experiment (NanTroSEIZE), the main goal of Integrated Ocean Drilling Program (IODP) Expedition 316, using the D/V Chikyu, was to investigate and understand the complex nature of tectonic activity in the accretionary prism system off Japan (Tobin and Kinoshita, 2006; Kimura et al., 2008; Strasser et al., 2009). One target of Expedition 316 was to study the impact of tectonic processes at the megasplay fault and frontal thrust area on the geochemical composition of deeply buried sediment (Screaton et al., 2009). Deep subsurface fluid flow and changes in depositional settings strongly influence the sulfur inventory in this sedimentary system (e.g., Riedinger et al., 2010).

Pyrite is often the most abundant iron sulfide in marine sediment (e.g., Goldhaber and Kaplan, 1975; Cornwell and Morse, 1987). In conjunction with its precursors (i.e., metastable iron sulfides), pyrite and its isotope composition can be used to investigate biogeochemical sulfur cycling in marine sediment (e.g., Goldhaber and Kaplan, 1974; Goldhaber et al., 1977; Howarth, 1979; Howarth and Jørgensen, 1984).

The abundance of pyrite in surface sediment is mainly controlled by the amount of buried total organic carbon (TOC) and availability of dissolved sulfate that drive microbial sulfate reduction and by the content of reactive iron, a scavenger for the produced sulfide (e.g., Jørgensen, 1977, 1982; Goldhaber and Kaplan, 1974; Berner, 1984). In surface sediment and deeply buried sediment, the interplay between sulfide production and inventory of reactive iron, which not only acts as a sulfide scavenger but can also drive oxidative sulfur cycling, exerts a major control on the formation and alteration of intermediate metastable iron sulfides such as mackinawite and greigite. These mineral phases can be transformed into pyrite by the addition of elemental sulfur (e.g., Goldhaber and Kaplan, 1975; Rickard and Luther, 2007, and references therein).

Microbial sulfate reduction produces sulfide strongly depleted in ${ }^{34} \mathrm{~S}$, causing enrichment of remaining sulfate in ${ }^{34}$ S (Thode et al., 1961; Jones and Starkey, 1957; Harrison and Thode, 1958; Kaplan and Rittenberg, 1964; Sim et al., 2011). Oxidative sulfur cycling (e.g., with reactive iron) can transform ${ }^{34} \mathrm{~S}$-depleted sulfide into sulfur intermediates, such as elemental sulfur or thiosulfate. The subsequent disproportionation of these sulfur intermediates into ${ }^{34} \mathrm{~S}$-enriched sulfate and ${ }^{34}$ S-depleted sulfide (e.g., Böttcher et al., 2005) can further increase the offset between isotopically heavy sulfate and light sulfide (Canfield and Thamdrup, 1994). Overall, these processes result in the formation of dissolved sulfide, monosulfides, and pyrite that are depleted in ${ }^{34} \mathrm{~S}$ relative to their sulfate source (e.g., Jørgensen, 1979; Canfield and Teske, 1996; Bottrell et al., 2009).

Under conditions in which sulfate enriched in ${ }^{34} \mathrm{~S}$ can be rapidly exchanged with seawater sulfate, such as close to the sediment/water interface or in the vicinity of seawater fluid conduits (highly permeable sediment such as sand or gravel layers or discontinuities such as faults), isotopically light sulfides can accumulate. Isotope compositions of sulfides approaching $-50 \%$ relative to $+20 \%$ for seawater sulfate are not uncommon under such circumstances. In sediment where the sulfate concentration decreases because of a diminished resupply with sulfate (i.e., through diffusion), the sulfate pool becomes isotopically heavier with depth (e.g., Goldhaber and Kaplan, 1980), resulting in the precipitation of iron sulfide minerals that are less depleted in ${ }^{34} \mathrm{~S}$. At the sulfate-methane transition, where sulfate is almost entirely consumed, iron sulfides are precipitated with the heaviest isotope composition compared to the upper sediment (Borowski et al., 2013). Under such conditions, the sulfur isotope composition of sulfides can become heavier than the isotope composition of the original sulfur source, which is often seawater sulfate.

Here we investigate the occurrence of iron sulfides in deeply buried sediment at the megasplay fault and the frontal thrust area and the relationship of the complex tectonic environment on the iron sulfide isotope signal. For this purpose, we analyzed samples from cores at the megasplay fault (Sites C0004 and C0008) and the toe of the accretionary prism (Sites C0006 and C0007) for iron sulfide phases and their isotopic signature.

\section{Methods and materials}

Samples were taken during Expedition 316 (see the "Expedition 316 methods" chapter [Expedition 316 Scientists, 2009a]). The shipping and storage temperature for all sediment cores was $-20^{\circ} \mathrm{C}$, which suppresses rapid oxidation. For determination of acid volatile sulfide (AVS) and chromium reducible sulfur (CRS) species, frozen wet samples (0.5-1 g) were treated with a two-step acid $\mathrm{Cr}$ (II) distillation method (Fossing and Jørgensen, 1989). AVS was extracted cold for $\sim 1 \mathrm{~h}$. This step was followed by $\mathrm{Cr}$ (II) extraction at $200^{\circ} \mathrm{C}$ for $\sim 2 \mathrm{~h}$. The released sulfide was trapped in a $5 \% \mathrm{w} / \mathrm{v}$ Zn acetate solution. After sonication, the trap samples were shaken, and an aliquot of each sample was diluted and analyzed spectrophotometrically by the methylene blue method (Cline, 
1969). The data are reported in dry weight units (Table T1). During the AVS extraction, mainly iron monosulfides, such as mackinawite, and $\sim 66 \%$ greigite were extracted. In the $\mathrm{Cr}$ (II) reduction step, mainly pyrite, elemental sulfur, and $\sim 33 \%$ greigite were extracted (e.g., Cornwell and Morse, 1987). For simplification, we refer to AVS as iron monosulfide and CRS as pyrite throughout the text.

To analyze the sulfur isotope composition of CRS $\left(\delta^{34} S\right.$-CRS), zinc sulfide was converted to silver sulfide $\left(\mathrm{Ag}_{2} \mathrm{~S}\right)$ with a $5 \%$ silver nitrate $\left(\mathrm{AgNO}_{3}\right)$ solution. The precipitate was rinsed with deionized water and washed with $1 \mathrm{M} \mathrm{NH}_{4} \mathrm{OH}$. In a final step, all $\mathrm{Ag}_{2} \mathrm{~S}$ precipitates were rinsed with deionized water and dried at $\sim 50^{\circ} \mathrm{C}$ in an oven overnight. Sulfur isotope measurements were performed by continuous flow gas source stable isotope ratio mass spectrometry (GS-IRMS) (model Delta V, Finnigan; Thermo Fisher Scientific, Waltham MA, USA). The sulfur isotope measurements were calibrated with reference materials NBS $127\left(\delta^{34} S=20.3 \%\right)$ and IAEA-SO-6 $\left(\delta^{34} S=\right.$ $-34.1 \%$ ) relative to the Vienna Cañon Diablo Troilite standard. The standard deviation $(1 \sigma)$ of replicate measurements of an in-house standard was $<0.2 \%$ o for $\delta^{34} S$ values. All samples were analyzed at the Max Planck Institute for Marine Microbiology, Bremen, Germany.

\section{Results}

Iron monosulfide and pyrite concentrations vary strongly at the investigated sites. At Site C0004, iron monosulfide concentrations are close to the detection limit with only a slight increase at $\sim 350$ meters below seafloor (mbsf) to a maximum of $\sim 6 \mathrm{ppm}$ (Fig. F1). In contrast, pyrite concentration reaches 1.3 wt $\%(13,000 \mathrm{ppm})$, with four main accumulation zones at $\sim 30,100,140$, and 250 mbsf. Pyrite sulfur isotope compositions ( $\delta^{34} \mathrm{~S}$-CRS) range from $-49 \%$ to $+47 \%$; the highest enrichment in ${ }^{34} \mathrm{~S}$ occurs in the zone dominated by mass transport (lithostratigraphic Subunit IIA) (Fig. F1). Low $\delta^{34} S$-CRS and pyrite concentrations are observed at the sediment/water interface and appear to coincide with transitions between different sedimentary units.

In the upper two-thirds of Unit II at Site C0006, iron monosulfide concentrations reach values of 550 ppm, whereas values are low for the remaining sediment column (Fig. F2). Except for a peak at 523 mbsf, pyrite concentrations are highest in the upper $\sim 45$ mbsf. Three features of the $\delta^{34} S$-CRS profile are remarkable. First, the isotope composition of pyrite shifts dramatically in the vicinity of the transition between lithostratigraphic Units I and II from $-40 \%$ to over $+20 \%$, coinciding with a drop in pyrite concentration. Second, $\delta^{34} S$-CRS displays a trend to lighter values with depth in Unit II. Third, a strong depletion in ${ }^{34} \mathrm{~S}$ was observed at the Pliocene/Pleistocene boundary followed by a maximum enrichment in ${ }^{34} \mathrm{~S}$ to $30 \%$ concurrent with a peak in pyrite concentration reaching almost $2 \mathrm{wt} \%$.

In Hole C0007D, iron monosulfide concentrations are only elevated in the upper deposits, with values below $220 \mathrm{ppm}$ followed by a downward decline (Fig. F3). Unlike iron monosulfide concentrations, pyrite concentrations are highest in the deeper sediment of Unit III, with a maximum value of $\sim 7700$ ppm. This pyrite concentration peak is accompanied by a sulfur isotope excursion from strongly negative $\delta^{34} \mathrm{~S}$ (less than $-48 \%$ ) to almost positive values $(-1.6 \%)$, succeeded by a return to strongly negative $\delta^{34} \mathrm{~S}(-39 \%$ ) at the boundary with Unit IV. Overall, the sulfur isotope profile of the deeper sediment in Hole C0007D shows a resemblance to the $\delta^{34}$ S-CRS profile at Site C0006.

Pyrite concentrations at Site C0008 are lowest between $\sim 40$ and 160 mbsf. Higher amounts of pyrite occur above and below this zone, with concentrations up to $1.5 \mathrm{wt} \%$ (Figs. F4, F5). Iron monosulfide concentrations show an inverse trend, with highest values $(<650 \mathrm{ppm})$ in the zone of lowest pyrite concentration. The $\delta^{34} S$-CRS composition in Hole $\mathrm{C} 0008 \mathrm{C}$ is nearly homogeneous throughout the sediment column, with a mean sulfur isotope composition of $-3 \%$ o $( \pm 10 \%)$. In only two zones is pyrite slightly more depleted in ${ }^{34} \mathrm{~S}$ ( $\sim 5$ and $95 \mathrm{mbsf}$ ) (Fig. F5).

Overall, the pattern of high pyrite concentrations coinciding with very low iron monosulfide concentrations and low pyrite concentrations coinciding with elevated monosulfide concentrations suggests that two modes of operation of sedimentary sulfur-iron cycling is present in the sediment from Nankai Trough. In the high pyrite formation mode, local sulfide formation may have temporally exceeded the availability of reactive iron, despite the high amount of detrital input (Screaton et al., 2009), therefore suppressing intense oxidative-reductive sulfur cycling. In contrast, intervals with low pyrite concentrations concurrent with iron monosulfides point to an iron-dominated sequence where the excess of reactive iron rapidly consumes newly formed free sulfide either by the formation of monosulfides or by oxidation, thus limiting the alteration from iron monosulfide to pyrite. 


\section{Acknowledgments}

This research used samples and data provided by Integrated Ocean Drilling Program (IODP) Expedition 316. We thank the crew and technical staff of the $\mathrm{D} / \mathrm{V}$ Chikyu. We are grateful for the assistance with sulfur isotope analysis by S. Lilienthal and for insightful comments by B.K. Frieda. Research support was provided by the Deutsche Forschungsgemeinschaft (DFG), Max Planck Society, US National Science Foundation (NSF), and the National Aeronautics and Space Administration Astrobiology Institute (NAI) Postdoctoral Program.

\section{References}

Berner, R.A., 1984. Sedimentary pyrite formation: an update. Geochim. Cosmochim. Acta, 48(4):605-615. doi:10.1016/0016-7037(84)90089-9

Borowski, W.S., Rodriguez, M.N., Paull, C.K., and Ussler, W., III, 2013. Are ${ }^{34}$ S-enriched authigenic sulfide minerals a proxy for elevated methane flux and gas hydrates in the geologic record? Mar. Pet. Geol., 43:381-395. doi:10.1016/j.marpetgeo.2012.12.009

Böttcher, M.E., Thamdrup, B., Gehre, M., and Theune, A., 2005. ${ }^{34} \mathrm{~S} /{ }^{32} \mathrm{~S}$ and ${ }^{18} \mathrm{O} /{ }^{16} \mathrm{O}$ fractionation during sulfur disproportionation by Desulfobulbus propionicus. Geomicrobiol. J., 22(5):219-226. doi:10.1080/

01490450590947751

Bottrell, S.H., Mortimer, R.J.G., Davies, I.M., Martyn Harvey, S., and Krom, M.D., 2009. Sulphur cycling in organic-rich marine sediments from a Scottish fjord. Sedimentology, 56(4):1159-1173. doi:10.1111/j.13653091.2008.01024.x

Canfield, D.E., and Teske, A., 1996. Late Proterozoic rise in atmospheric oxygen concentration inferred from phylogenetic and sulphur-isotope studies. Nature (London, U. K.), 328:127-132. doi:10.1038/382127a0

Canfield, D.E., and Thamdrup, B., 1994. The production of ${ }^{34} \mathrm{~S}$-depleted sulfide during bacterial disproportionation of elemental sulfur. Science, 266(5193):1973-1975. doi:10.1126/science.11540246

Cline, J.D., 1969. Spectrophotometric determination of hydrogen sulfide in natural waters. Limnol. Oceanogr., 14(3):454-458. doi:10.4319/1o.1969.14.3.0454

Cornwell, J.C., and Morse, J.W., 1987. The characterization of iron sulfide minerals in anoxic marine sediments. Mar. Chem., 22(2-4):193-206. doi:10.1016/03044203(87)90008-9

Expedition 316 Scientists, 2009a. Expedition 316 methods. In Kinoshita, M., Tobin, H., Ashi, J., Kimura, G., Lallemant, S., Screaton, E.J., Curewitz, D., Masago, H., Moe, K.T., and the Expedition 314/315/316 Scientists, Proc. IODP, 314/315/316: Washington, DC (Integrated Ocean Drilling Program Management International, Inc.). doi:10.2204/iodp.proc.314315316.132.2009

Expedition 316 Scientists, 2009b. Expedition 316 Site C0004. In Kinoshita, M., Tobin, H., Ashi, J., Kimura, G., Lallemant, S., Screaton, E.J., Curewitz, D., Masago, H.,
Moe, K.T., and the Expedition 314/315/316 Scientists, Proc. IODP, 314/315/316: Washington, DC (Integrated Ocean Drilling Program Management International, Inc.). doi:10.2204/iodp.proc.314315316.133.2009

Expedition 316 Scientists, 2009c. Expedition 316 Site C0006. In Kinoshita, M., Tobin, H., Ashi, J., Kimura, G., Lallemant, S., Screaton, E.J., Curewitz, D., Masago, H., Moe, K.T., and the Expedition 314/315/316 Scientists, Proc. IODP, 314/315/316: Washington, DC (Integrated Ocean Drilling Program Management International, Inc.). doi:10.2204/iodp.proc.314315316.134.2009

Expedition 316 Scientists, 2009d. Expedition 316 Site C0007. In Kinoshita, M., Tobin, H., Ashi, J., Kimura, G., Lallemant, S., Screaton, E.J., Curewitz, D., Masago, H., Moe, K.T., and the Expedition 314/315/316 Scientists, Proc. IODP, 314/315/316: Washington, DC (Integrated Ocean Drilling Program Management International, Inc.). doi:10.2204/iodp.proc.314315316.135.2009

Expedition 316 Scientists, 2009e. Expedition 316 Site C0008. In Kinoshita, M., Tobin, H., Ashi, J., Kimura, G., Lallemant, S., Screaton, E.J., Curewitz, D., Masago, H., Moe, K.T., and the Expedition 314/315/316 Scientists, Proc. IODP, 314/315/316: Washington, DC (Integrated Ocean Drilling Program Management International, Inc.). doi:10.2204/iodp.proc.314315316.136.2009

Fossing, H., and Jørgensen, B.B., 1989. Measurement of bacterial sulfate reduction in sediments: evaluation of a single-step chromium reduction method. Biogeochemistry, 8(3):205-222. doi:10.1007/BF00002889

Goldhaber, M.B., Aller, R.C., Cochran, J.K., Rosenfeld, J.K., Martens, C.S., and Berner, R.A., 1977. Sulfate reduction, diffusion and bioturbation in Long Island Sound sediments: report of the FOAM group. Am. J. Sci., 277(3):193-237. doi:10.2475/ajs.277.3.193

Goldhaber, M.B., and Kaplan, I.R., 1974. The sulfur cycle. In Goldberg, E.D. (Ed.), The Sea (Vol. 5): Marine Chemistry: The Sedimentary Cycle: New York (Wiley-Interscience), 569-655.

Goldhaber, M.B., and Kaplan, I.R., 1975. Controls and consequences of sulfate reduction rates in recent marine sediments. Soil Sci., 119(1):42-55. doi:10.1097/ 00010694-197501000-00008

Goldhaber, M.B., and Kaplan, I.R., 1980. Mechanisms of sulfur incorporation and isotope fractionation during early diagenesis in sediments of the Gulf of California. Mar. Chem., 9(2):95-143. doi:10.1016/03044203(80)90063-8

Harrison, A.G., and Thode, H.G., 1958. Mechanism of the bacterial reduction of sulphate from isotope fractionation studies. Trans. Faraday Soc., 54:84-92. doi:10.1039/tf9585400084

Howarth R.W., 1979. Pyrite: its rapid formation in a salt marsh and its importance to ecosystem metabolism. Science, 203(4375):49-51. doi:10.1126/science. 203.4375.49

Howarth, R.W., and Jørgensen, B.B., 1984. Formation of ${ }^{35} \mathrm{~S}$-labeled elemental sulfur and pyrite in coastal marine sediments (Limfjorden and Kysing Fjord, Denmark) during short-term ${ }^{35} \mathrm{SO}_{4}{ }^{2-}$ reduction measurements. Geo- 
chim. Cosmochim. Acta, 48(9):1807-1818. doi:10.1016/ 0016-7037(84)90034-6

Jones, G.E., and Starkey, R.L., 1957. Fractionation of stable isotopes of sulfur by microorganisms and their role in deposition of native sulfur. Appl. Microbio., 5(2):111118. http://www.ncbi.nlm.nih.gov/pmc/articles/ PMC1057268/

Jørgensen, B.B., 1977. The sulfur cycle of a coastal marine sediment (Limfjorden, Denmark). Limnol. Oceanogr., 22(5):814-832.doi:10.4319/1o.1977.22.5.0814

Jørgensen, B.B., 1979. A theoretical model of the stable sulfur isotope distribution in marine sediments. Geochim. Cosmochim. Acta, 43(3):363-374. doi:10.1016/00167037(79)90201-1

Jørgensen, B.B., 1982. Mineralization of organic matter in the seabed-the role of sulphate reduction. Nature (London, U. K.), 296(5858):643-645. doi:10.1038/296643a0

Kaplan, I.R., and Rittenberg, S.C., 1964. Microbiological fractionation of sulfur isotopes. Microbiology, 34(2):195212. doi:10.1099/00221287-34-2-195

Kimura, G., Screaton, E.J., Curewitz, D., and the Expedition 316 Scientists, 2008. NanTroSEIZE Stage 1A: NanTroSEIZE shallow megasplay and frontal thrusts. IODP Prel. Rept., 316. doi:10.2204/iodp.pr.316.2008

Mills, H.J., Reese, B.K., Shepard, A.K., Riedinger, N., Dowd, S.E., Morono, Y., and Inagaki, F., 2012. Characterization of metabolically active bacterial populations in subseafloor Nankai Trough sediments above, within, and below the sulfate-methane transition zone. Front. Microbiol., 3:113. doi:10.3389/fmicb.2012.00113

Rickard, D., and Luther, G.W., III, 2007. Chemistry of iron sulfides. Chem. Rev., 107(2):514-562. doi:10.1021/ cr0503658
Riedinger, N., Brunner, B., Formolo, M.J., Solomon, E., Kasten, S., Strasser, M., and Ferdelman, T.G., 2010. Oxidative sulfur cycling in the deep biosphere of the Nankai Trough, Japan. Geology, 38(9):851-854. doi:10.1130/ G31085.1

Screaton, E.J., Kimura, G., Curewitz, D., and the Expedition 316 Scientists, 2009. Expedition 316 summary. In Kinoshita, M., Tobin, H., Ashi, J., Kimura, G., Lallemant, S., Screaton, E.J., Curewitz, D., Masago, H., Moe, K.T., and the Expedition 314/315/316 Scientists, Proc. IODP, 314/315/316: Washington, DC (Integrated Ocean Drilling Program Management International, Inc.). doi:10.2204/iodp.proc.314315316.131.2009

Sim, M.S., Bosak, T., and Ono, S., 2011. Large sulfur isotope fractionation does not require disproportionation. Science, 333(6038):74-77. doi:10.1126/science. 1205103

Strasser, M., Moore, G.F., Kimura, G., Kitamura, Y., Kopf, A.J., Lallemant, S., Park, J.-O., Screaton, E.J., Su, X., Underwood, M.B., and Zhao, X., 2009. Origin and evolution of a splay fault in the Nankai accretionary wedge. Nat. Geosci., 2(9):648-652. doi:10.1038/ngeo609

Thode, H.G., Monster, J., and Dunford, H.B., 1961. Sulphur isotope geochemistry. Geochim. Cosmochim. Acta, 25(3):158-174. doi:10.1016/0016-7037(61)90074-6

Tobin, H.J., and Kinoshita, M., 2006. NanTroSEIZE: the IODP Nankai Trough Seismogenic Zone Experiment. Sci. Drill., 2:23-27. doi:10.2204/iodp.sd.2.06.2006

Initial receipt: 13 November 2013

Acceptance: 3 February 2014

Publication: 24 March 2014

MS 314315316-223 
Figure F1. Iron monosulfide (AVS) and pyrite (CRS) concentrations, sulfur isotope composition of pyrite $\left(\delta^{34} S\right.$-CRS relative to Vienna Cañon Diablo Troilite), and major lithostratigraphic units at Site C0004. Lithostratigraphic units depicted as identified during NanTroSEIZE Stage 1 drilling (see the "Expedition 316 Site C0004" chapter [Expedition 316 Scientists, 2009b]). CRS data in upper 60 mbsf is from Mills et al., 2012.

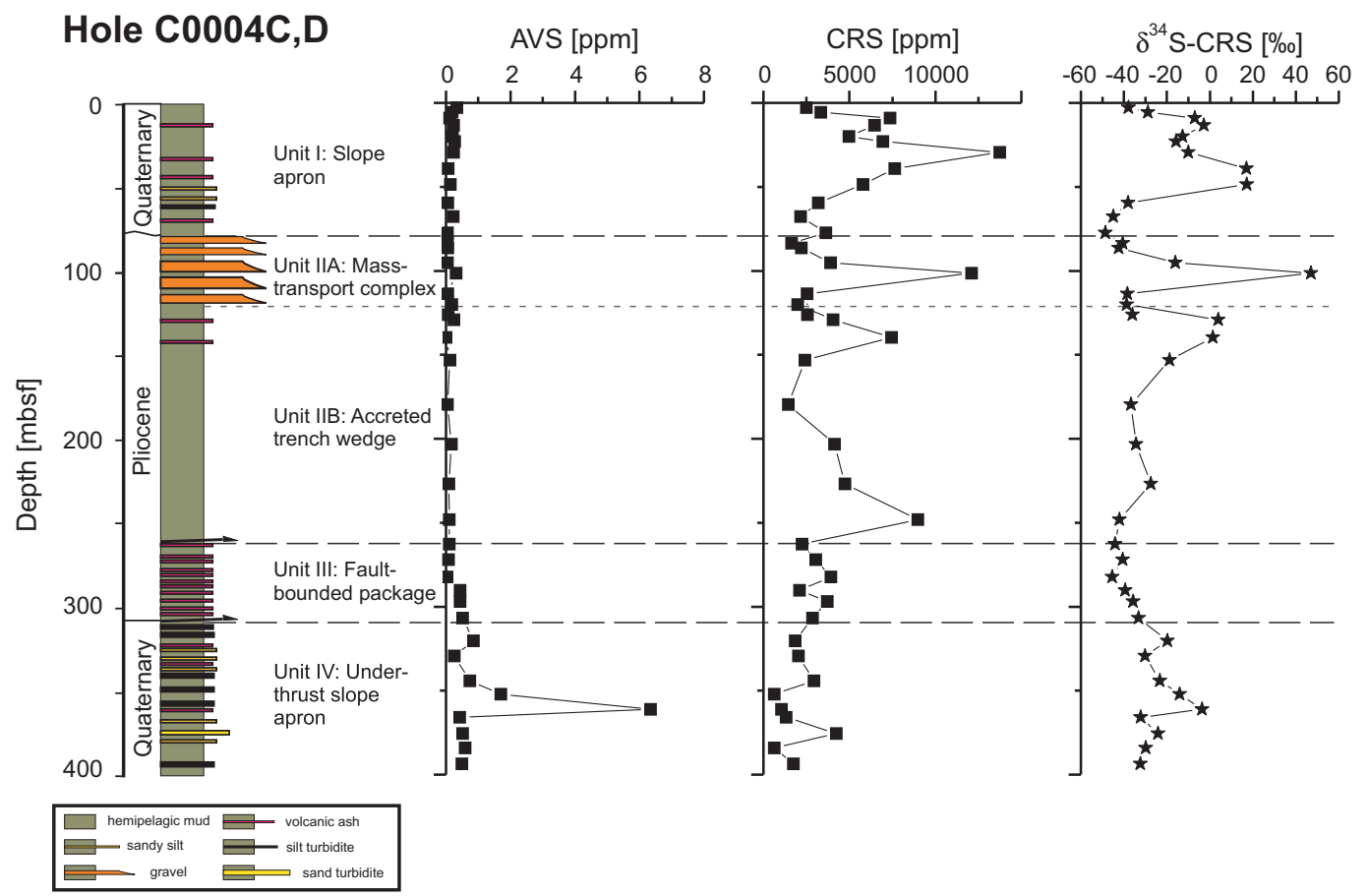


Figure F2. Iron monosulfide (AVS) and pyrite (CRS) concentrations, sulfur isotope composition of pyrite $\left(\delta^{34} S\right.$-CRS relative to Vienna Cañon Diablo Troilite), and major lithostratigraphic units at Site C0006. Lithostratigraphic units depicted as identified during NanTroSEIZE Stage 1 drilling (see the "Expedition 316 Site C0006" chapter [Expedition 316 Scientists, 2009c]).

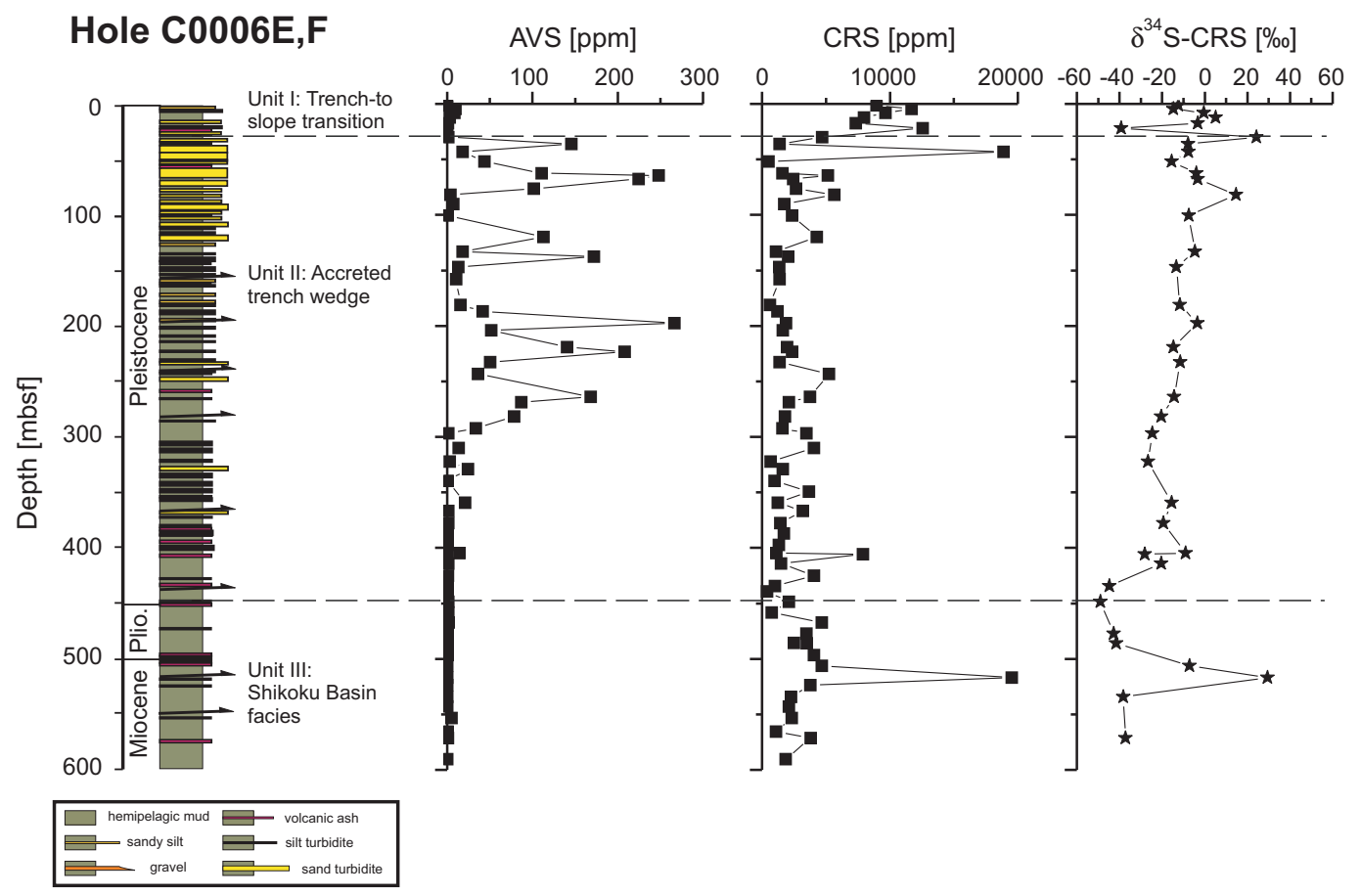


Figure F3. Iron monosulfide (AVS) and pyrite (CRS) concentrations, sulfur isotope composition of pyrite $\left(\delta^{34} S\right.$-CRS relative to Vienna Cañon Diablo Troilite), and major lithostratigraphic units in Hole C0007D. Lithostratigraphic units depicted as identified during NanTroSEIZE Stage 1 drilling (see the "Expedition 316 Site C0007" chapter [Expedition 316 Scientists, 2009d]).

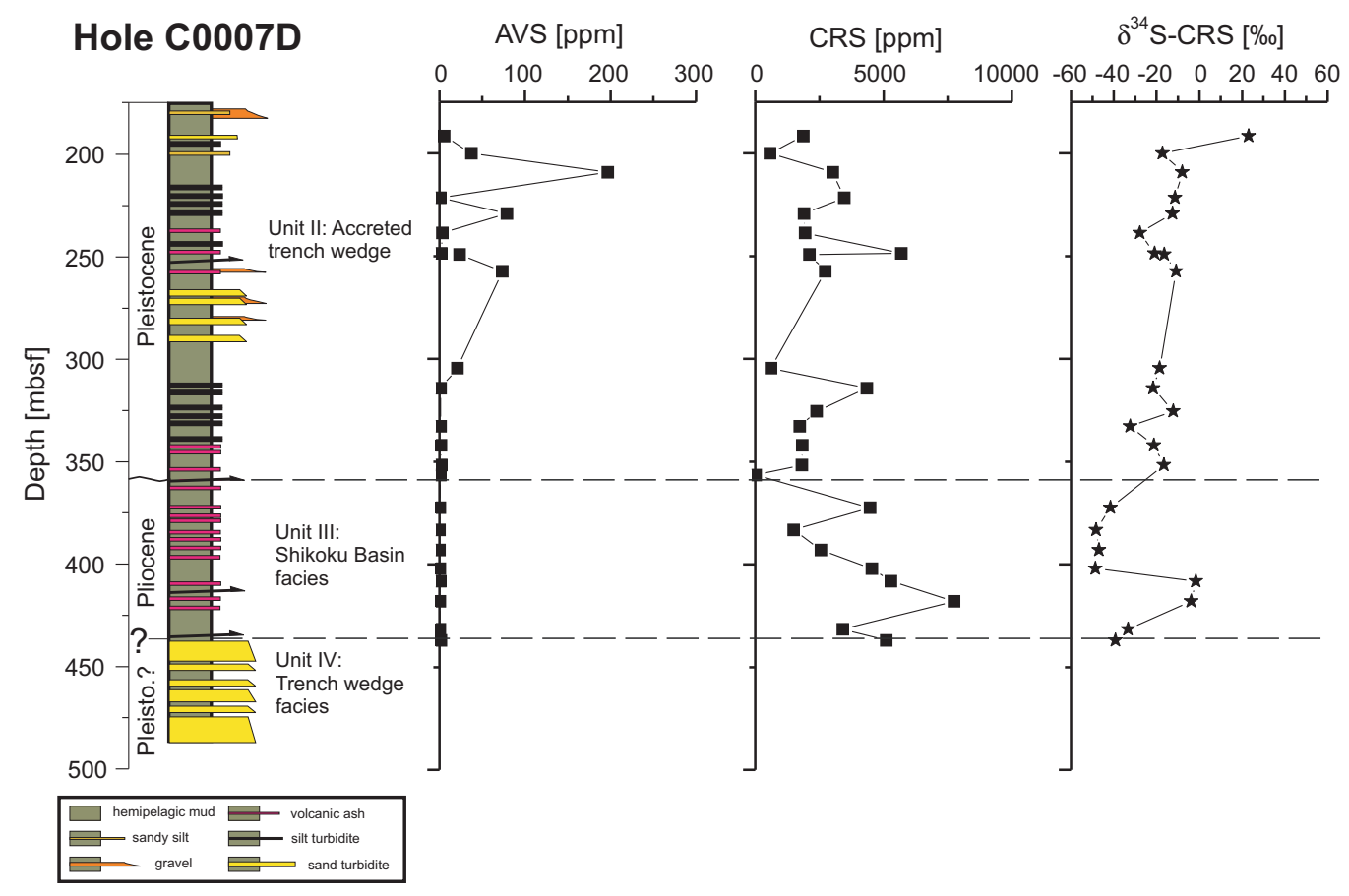


Figure F4. Iron monosulfide (AVS) and pyrite (CRS) concentrations of sediment in Hole C0008A. Major lithostratigraphic units depicted as identified during NanTroSEIZE Stage 1 drilling (see the "Expedition 316 Site C0008" chapter [Expedition 316 Scientists, 2009e]).

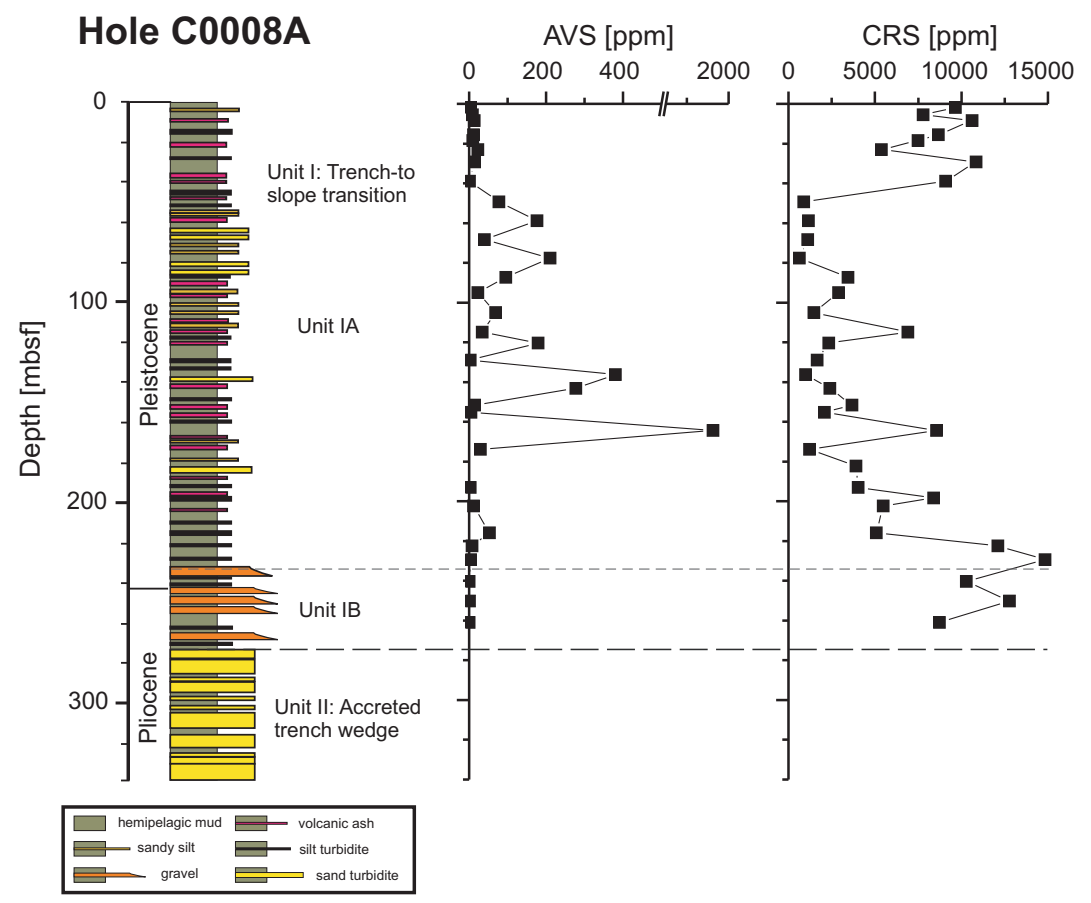


Figure F5. Iron monosulfide (AVS) and pyrite (CRS) concentrations, sulfur isotope composition of pyrite $\left(\delta^{34} S\right.$-CRS relative to Vienna Cañon Diablo Troilite), and major lithostratigraphic units in Hole C0008C. Lithostratigraphic units depicted as identified during NanTroSEIZE Stage 1 drilling (see the "Expedition 316 Site C0008" chapter [Expedition 316 Scientists, 2009e]).

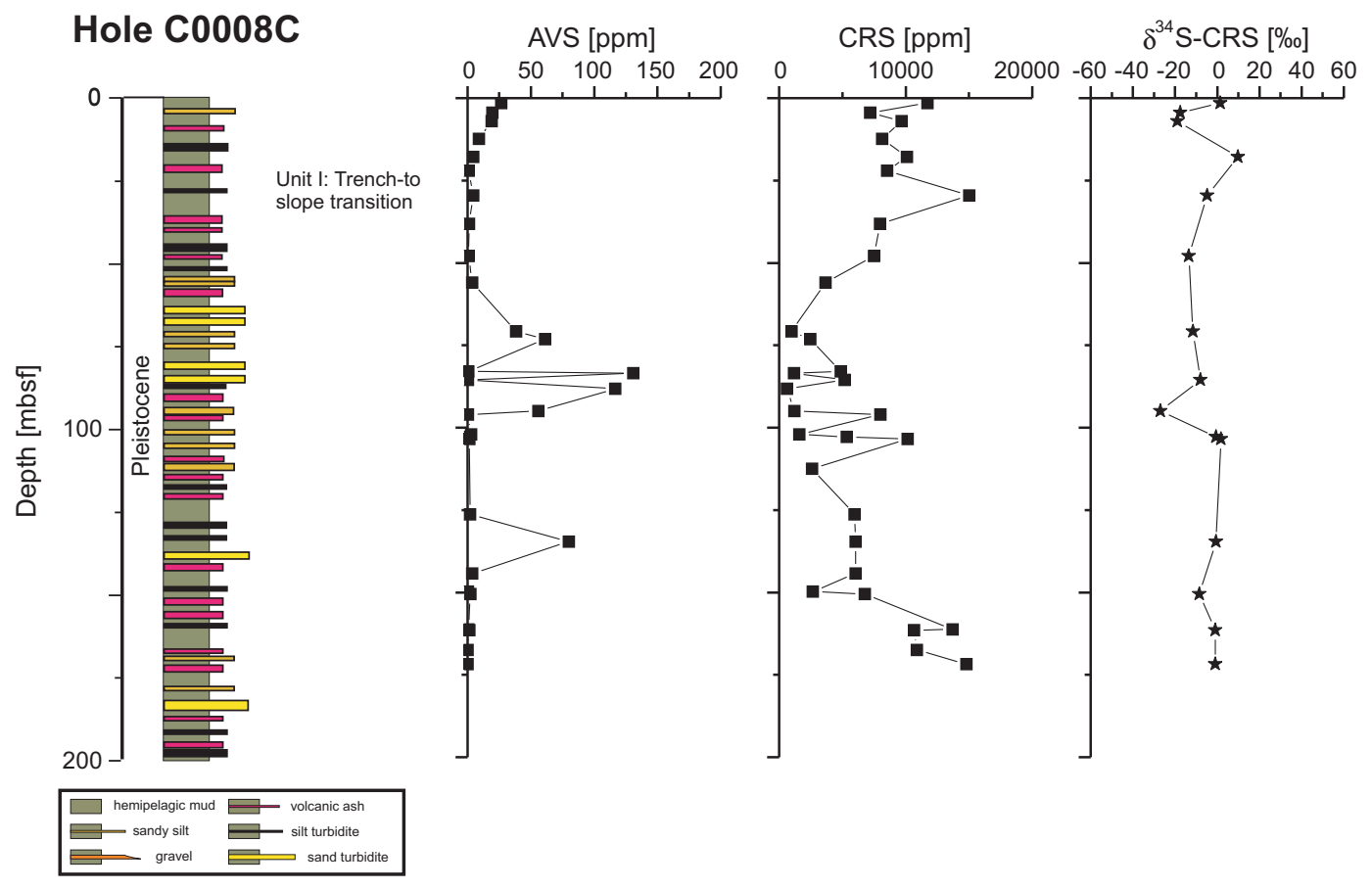


Table T1. Summary of solid-phase sulfur data, Expedition 316. (Continued on next page.)

\begin{tabular}{|c|c|c|c|c|}
\hline $\begin{array}{l}\text { Core, section, } \\
\text { interval }(\mathrm{cm})\end{array}$ & $\begin{array}{l}\text { Depth } \\
\text { (mbsf) }\end{array}$ & $\begin{array}{c}\text { AVS } \\
(p p m)\end{array}$ & $\begin{array}{c}\text { CRS } \\
(\mathrm{ppm})\end{array}$ & $\begin{array}{c}\delta^{34} \text { S-CRS } \\
\text { (\%o VCDT) }\end{array}$ \\
\hline \multicolumn{5}{|l|}{ 316-C0004C- } \\
\hline $1 \mathrm{H}-3$ & 2.73 & 0.34 & $2,503.9$ & -37.9 \\
\hline $1 \mathrm{H}-6$ & 5.54 & 0.19 & $3,325.2$ & -28.7 \\
\hline $2 \mathrm{H}-3$ & 9.09 & 0.11 & $7,365.9$ & -7.0 \\
\hline $2 \mathrm{H}-7$ & 13.38 & 0.23 & $6,467.7$ & -2.8 \\
\hline $3 \mathrm{H}-5$ & 20.01 & 0.20 & $4,975.7$ & -12.7 \\
\hline $3 \mathrm{H}-8$ & 22.87 & 0.27 & $6,935.7$ & -15.7 \\
\hline $4 \mathrm{H}-4$ & 29.52 & 0.23 & $13,734.5$ & -10.0 \\
\hline $5 \mathrm{H}-4$ & 39.17 & 0.07 & $7,630.5$ & 17.0 \\
\hline $6 \mathrm{H}-4$ & 48.58 & 0.13 & $5,788.2$ & 17.2 \\
\hline $7 \mathrm{H}-6$ & 59.45 & 0.06 & $3,185.8$ & -38.0 \\
\hline $8 \mathrm{H}-4$ & 67.74 & 0.22 & $2,155.3$ & -44.9 \\
\hline $9 \mathrm{H}-4$ & 77.25 & 0.05 & $3,619.8$ & -48.6 \\
\hline $10 \mathrm{H}-3$ & 83.58 & 0.05 & $1,646.6$ & -40.6 \\
\hline $11 \mathrm{H}-2$ & 86.35 & 0.06 & $2,200.6$ & -42.4 \\
\hline $12 X-6$ & 95.12 & 0.05 & $3,900.3$ & -15.9 \\
\hline $13 X-3$ & 101.40 & 0.31 & $12,109.5$ & 47.1 \\
\hline $14 X-5$ & 113.72 & 0.06 & $2,533.4$ & -38.4 \\
\hline $15 X-7$ & 126.05 & 0.07 & $2,565.8$ & -35.9 \\
\hline \multicolumn{5}{|l|}{ 316-C0004D- } \\
\hline $3 R-2$ & 119.99 & 0.18 & $1,989.6$ & -38.7 \\
\hline $4 \mathrm{R}-2$ & 129.17 & 0.25 & $4,058.7$ & 3.9 \\
\hline $5 R-3$ & 139.69 & 0.00 & $7,445.7$ & 1.4 \\
\hline $7 R-2$ & 153.08 & 0.12 & $2,411.1$ & -18.7 \\
\hline $13 R-2$ & 179.47 & 0.04 & $1,437.8$ & -36.7 \\
\hline $16 \mathrm{R}-2$ & 203.20 & 0.17 & $4,140.1$ & -34.3 \\
\hline $19 \mathrm{R}-2$ & 226.82 & 0.09 & $4,737.7$ & -27.4 \\
\hline 23R-1 & 248.12 & 0.10 & $8,974.5$ & -42.1 \\
\hline $26 \mathrm{R}-3$ & 262.69 & 0.10 & $2,250.2$ & -44.1 \\
\hline $28 \mathrm{R}-2$ & 271.91 & 0.08 & $3,050.2$ & -40.5 \\
\hline $30 R-3$ & 282.19 & 0.03 & $3,913.5$ & -45.4 \\
\hline $32 R-3$ & 290.21 & 0.44 & $2,098.0$ & -39.4 \\
\hline $34 \mathrm{R}-1$ & 296.75 & 0.44 & $3,707.9$ & -35.7 \\
\hline $36 \mathrm{R}-2$ & 306.80 & 0.51 & $2,852.5$ & -33.2 \\
\hline $39 R-2$ & 320.29 & 0.85 & $1,836.9$ & -19.8 \\
\hline $41 R-2$ & 329.45 & 0.26 & $2,030.7$ & -30.2 \\
\hline $44 \mathrm{R}-3$ & 344.20 & 0.74 & $2,944.1$ & -23.2 \\
\hline $46 \mathrm{R}-2$ & 352.06 & 1.70 & 620.8 & -14.0 \\
\hline $48 \mathrm{R}-2$ & 361.16 & 6.34 & $1,048.5$ & -3.6 \\
\hline 49R-2 & 365.81 & 0.42 & $1,326.5$ & -32.2 \\
\hline $51 R-2$ & 375.63 & 0.51 & $4,236.6$ & -24.1 \\
\hline $53 \mathrm{R}-2$ & 384.10 & 0.59 & 628.4 & -29.9 \\
\hline $55 R-2$ & 393.60 & 0.49 & $1,735.1$ & -32.3 \\
\hline \multicolumn{5}{|l|}{ 316-C0006E- } \\
\hline $1 \mathrm{H}-2$ & 1.32 & 0.19 & $8,940.9$ & -12.4 \\
\hline $1 \mathrm{H}-5$ & 4.36 & 9.72 & $11,705.5$ & -14.6 \\
\hline $2 \mathrm{H}-3$ & 7.91 & 8.47 & $9,639.4$ & -0.5 \\
\hline $2 \mathrm{H}-7$ & 12.21 & 2.74 & $7,978.3$ & 5.1 \\
\hline $3 \mathrm{H}-3$ & 17.40 & 0.63 & $7,330.3$ & -3.2 \\
\hline $3 \mathrm{H}-7$ & 21.77 & 0.16 & $12,569.0$ & -39.2 \\
\hline $4 \mathrm{H}-5$ & 30.04 & 1.36 & $4,707.5$ & 24.2 \\
\hline $5 \mathrm{H}-3$ & 35.95 & 145.70 & $1,379.3$ & -7.8 \\
\hline $7 \mathrm{H}-4$ & 43.04 & 17.90 & $18,871.9$ & -7.6 \\
\hline $8 \mathrm{H}-4$ & 51.91 & 43.60 & 510.6 & -15.5 \\
\hline $9 \mathrm{H}-5$ & 62.53 & 110.60 & $1,606.0$ & -3.9 \\
\hline $10 \mathrm{H}-8$ & 64.59 & 248.10 & $5,150.5$ & NA \\
\hline $11 \mathrm{H}-4$ & 67.81 & 224.50 & $2,421.7$ & -3.2 \\
\hline $12 \mathrm{H}-6$ & 76.41 & 101.60 & $2,649.5$ & NA \\
\hline $15 X-4$ & 81.87 & 3.74 & $5,654.5$ & 14.7 \\
\hline $16 X-2$ & 90.23 & 7.29 & $1,732.8$ & NA \\
\hline $17 X-3$ & 100.43 & 0.25 & $2,355.9$ & -7.4 \\
\hline $19 X-5$ & 119.92 & 112.70 & $4,290.1$ & NA \\
\hline $20 x-7$ & 133.01 & 18.10 & $1,104.3$ & -4.7 \\
\hline $21 X-3$ & 137.54 & 172.00 & $2,045.6$ & NA \\
\hline $22 X-3$ & 147.00 & 13.00 & $1,341.6$ & -13.3 \\
\hline $23 X-4$ & 157.91 & 10.40 & $1,377.9$ & NA \\
\hline $25 X-7$ & 180.96 & 15.40 & 620.0 & -11.7 \\
\hline $26 X-4$ & 186.80 & 41.70 & $1,206.9$ & NA \\
\hline $27 X-5$ & 197.68 & 266.60 & $1,878.2$ & -3.4 \\
\hline
\end{tabular}

\begin{tabular}{|c|c|c|c|c|}
\hline $\begin{array}{l}\text { Core, section, } \\
\text { interval }(\mathrm{cm})\end{array}$ & $\begin{array}{l}\text { Depth } \\
\text { (mbsf) }\end{array}$ & $\begin{array}{c}\text { AVS } \\
(\mathrm{ppm})\end{array}$ & $\begin{array}{c}\text { CRS } \\
(\mathrm{ppm})\end{array}$ & $\begin{array}{c}\delta^{34} \text { S-CRS } \\
\text { (\%o VCDT) }\end{array}$ \\
\hline $28 X-3$ & 203.99 & 51.45 & $1,618.2$ & NA \\
\hline $29 X-7$ & 219.21 & 140.80 & $1,963.5$ & -14.7 \\
\hline $30 x-3$ & 223.35 & 208.10 & $2,343.0$ & NA \\
\hline $31 \times-3$ & 232.50 & 50.20 & $1,368.8$ & -11.4 \\
\hline $32 X-4$ & 243.40 & 36.07 & $5,221.0$ & NA \\
\hline $34 X-5$ & 263.81 & 168.40 & $3,736.2$ & -14.4 \\
\hline $35 X-2$ & 268.87 & 87.00 & $2,084.9$ & NA \\
\hline $36 X-4$ & 281.74 & 78.30 & $1,786.2$ & -20.5 \\
\hline $37 X-5$ & 292.30 & 33.70 & $1,580.6$ & NA \\
\hline $38 X-2$ & 296.80 & 1.28 & $3,480.1$ & -24.7 \\
\hline $39 X-4$ & 309.88 & 13.30 & $4,049.5$ & NA \\
\hline $40 X-7$ & 322.21 & 2.98 & 674.0 & -26.6 \\
\hline $41 X-4$ & 329.02 & 24.21 & $1,616.4$ & NA \\
\hline $42 X-5$ & 339.78 & 0.50 & 973.7 & NA \\
\hline $43 X-5$ & 349.30 & 550.40 & $3,664.9$ & NA \\
\hline $44 X-5$ & 359.18 & 21.10 & $1,235.6$ & -15.5 \\
\hline $45 X-4$ & 366.86 & 1.19 & $3,187.4$ & NA \\
\hline $46 X-5$ & 377.80 & 1.20 & $1,415.6$ & -19.4 \\
\hline $47 X-5$ & 386.91 & 0.27 & $1,707.8$ & NA \\
\hline $48 X-5$ & 397.19 & 0.56 & $1,318.3$ & NA \\
\hline $49 X-4$ & 404.89 & 14.20 & $1,116.9$ & -9.0 \\
\hline \multicolumn{5}{|l|}{ 316-C0006F- } \\
\hline $2 \mathrm{R}-2$ & 405.72 & 1.19 & $2,205.9$ & -22.6 \\
\hline $3 R-1$ & 414.20 & 0.20 & $7,889.4$ & -28.0 \\
\hline $4 \mathrm{R}-2$ & 425.09 & 1.24 & $1,482.8$ & -20.5 \\
\hline $5 R-1$ & 434.37 & 0.84 & $4,067.1$ & NA \\
\hline $6 \mathrm{R}-1$ & 439.25 & 0.21 & $1,010.1$ & -44.8 \\
\hline 7R-1 & 448.53 & 0.34 & 388.9 & NA \\
\hline $8 R-1$ & 458.22 & 1.10 & $2,087.4$ & -49.0 \\
\hline $9 \mathrm{R}-1$ & 467.24 & 1.29 & 758.4 & NA \\
\hline $10 R-1$ & 477.37 & 1.56 & $4,667.7$ & NA \\
\hline $11 \mathrm{R}-1$ & 485.57 & 0.40 & $3,458.4$ & -42.7 \\
\hline $12 \mathrm{R}-2$ & 496.64 & 0.39 & $3,507.8$ & -41.6 \\
\hline $13 R-2$ & 506.10 & 0.46 & $4,049.8$ & NA \\
\hline $14 \mathrm{R}-2$ & 516.80 & 0.05 & $4,665.7$ & -7.2 \\
\hline $15 R-1$ & 523.70 & 0.11 & $19,529.0$ & 29.4 \\
\hline $16 \mathrm{R}-1$ & 534.21 & 0.11 & $3,768.0$ & NA \\
\hline 17R-1 & 542.86 & 0.06 & $2,267.6$ & -38.2 \\
\hline $18 \mathrm{R}-1$ & 553.31 & 0.11 & $2,105.2$ & NA \\
\hline $19 R-3$ & 565.46 & 4.85 & $2,333.9$ & NA \\
\hline $20 \mathrm{R}-1$ & 571.34 & 0.27 & $1,084.7$ & NA \\
\hline $22 \mathrm{R}-1$ & 590.21 & 0.75 & $3,816.1$ & -37.2 \\
\hline $23 R-1$ & 594.00 & 0.08 & $1,850.1$ & NA \\
\hline \multicolumn{5}{|l|}{ 316-C0007D- } \\
\hline $3 R-2$ & 191.59 & 5.60 & $1,873.8$ & 23.1 \\
\hline $4 \mathrm{R}-1$ & 199.93 & 37.50 & 575.1 & -17.1 \\
\hline $5 R-1$ & 209.21 & 196.70 & $3,015.6$ & -8.0 \\
\hline $6 \mathrm{R}-3$ & 221.65 & 0.99 & $3,468.0$ & -11.4 \\
\hline 7R-1 & 229.19 & 78.80 & $1,899.3$ & -12.5 \\
\hline $8 \mathrm{R}-1$ & 238.65 & 3.38 & $1,946.7$ & -27.8 \\
\hline $9 R-2,23-40$ & 248.74 & 2.00 & $5,695.9$ & -21.0 \\
\hline 9R-2, 57-79 & 249.10 & 23.50 & $2,117.2$ & -16.4 \\
\hline $10 \mathrm{R}-1$ & 257.25 & 73.60 & $2,733.4$ & -10.8 \\
\hline $15 \mathrm{R}-1$ & 304.53 & 20.80 & 612.0 & -18.6 \\
\hline $16 \mathrm{R}-1$ & 314.16 & 1.18 & $4,351.9$ & -21.6 \\
\hline $17 R-3$ & 325.50 & 179.70 & $2,392.9$ & -12.2 \\
\hline $18 \mathrm{R}-1$ & 332.83 & 1.06 & $1,733.6$ & -32.2 \\
\hline $19 R-1$ & 342.02 & 1.47 & $1,829.5$ & -21.2 \\
\hline $20 \mathrm{R}-1$ & 351.66 & 2.07 & $1,817.8$ & -16.6 \\
\hline $21 R-1$ & 356.48 & 0.71 & 20.1 & NA \\
\hline $22 \mathrm{R}-2$ & 372.36 & 0.21 & $4,472.2$ & -41.6 \\
\hline $23 R-3$ & 383.16 & 0.20 & $1,502.2$ & -48.3 \\
\hline $24 R-3$ & 393.03 & 0.16 & $2,554.5$ & -46.9 \\
\hline $25 R-3$ & 402.07 & 0.21 & $4,551.4$ & -48.6 \\
\hline $26 \mathrm{R}-1$ & 408.21 & 0.72 & $5,285.5$ & -1.6 \\
\hline $27 R-1$ & 417.87 & 0.40 & $7,742.9$ & -3.8 \\
\hline $28 R-4$ & 431.59 & 0.44 & $3,411.5$ & -33.3 \\
\hline $29 \mathrm{R}-1$ & 437.00 & 1.82 & $5,100.7$ & -39.1 \\
\hline
\end{tabular}


Table T1 (continued).

\begin{tabular}{|c|c|c|c|c|}
\hline $\begin{array}{l}\text { Core, section, } \\
\text { interval }(\mathrm{cm})\end{array}$ & $\begin{array}{l}\text { Depth } \\
\text { (mbsf) }\end{array}$ & $\begin{array}{l}\text { AVS } \\
\text { (ppm) }\end{array}$ & $\begin{array}{l}\text { CRS } \\
\text { (ppm) }\end{array}$ & $\begin{array}{c}\delta^{34} \mathrm{~S}-\mathrm{CRS} \\
\text { (\%o VCDT) }\end{array}$ \\
\hline \multicolumn{5}{|l|}{ 316-C0008A- } \\
\hline $1 \mathrm{H}-3$ & 1.75 & 3.71 & $9,643.8$ & NA \\
\hline $1 \mathrm{H}-7$ & 5.54 & 8.10 & $7,773.3$ & NA \\
\hline $2 \mathrm{H}-2$ & 8.46 & 13.50 & $10,610.3$ & NA \\
\hline $2 \mathrm{H}-8$ & 15.55 & 11.20 & $8,660.2$ & NA \\
\hline $3 \mathrm{H}-3$ & 18.52 & 9.42 & $7,491.1$ & NA \\
\hline $3 \mathrm{H}-8$ & 23.10 & 22.20 & $5,363.7$ & NA \\
\hline $4 \mathrm{H}-4$ & 29.30 & 14.50 & $10,837.6$ & NA \\
\hline $5 \mathrm{H}-4$ & 38.83 & 0.68 & $9,093.5$ & NA \\
\hline $6 \mathrm{H}-5$ & 49.38 & 77.30 & 874.0 & NA \\
\hline $7 \mathrm{H}-5$ & 58.73 & 176.60 & $1,159.4$ & NA \\
\hline $8 \mathrm{H}-5$ & 68.37 & 39.70 & $1,118.7$ & NA \\
\hline $9 \mathrm{H}-5$ & 77.70 & 210.60 & 620.1 & NA \\
\hline $10 \mathrm{H}-6$ & 87.37 & 95.00 & $3,437.4$ & NA \\
\hline $11 \mathrm{H}-4$ & 94.87 & 22.60 & $2,895.0$ & NA \\
\hline $12 \mathrm{H}-5$ & 105.05 & 68.70 & $1,464.3$ & NA \\
\hline $13 \mathrm{H}-5$ & 114.93 & 34.10 & $6,895.1$ & NA \\
\hline $15 \mathrm{H}-2$ & 120.31 & 179.50 & $2,323.1$ & NA \\
\hline $16 \mathrm{H}-4$ & 129.00 & 2.85 & $1,647.1$ & NA \\
\hline $17 \mathrm{H}-6$ & 136.28 & 380.50 & 991.8 & NA \\
\hline $18 \mathrm{H}-3$ & 143.15 & 277.60 & $2,389.7$ & NA \\
\hline $19 \mathrm{H}-2$ & 151.52 & 14.20 & $3,676.3$ & NA \\
\hline $20 \mathrm{H}-3$ & 155.24 & 5.17 & $2,077.1$ & NA \\
\hline $21 \mathrm{H}-5$ & 164.26 & 1962.70 & $8,569.0$ & NA \\
\hline $22 \mathrm{H}-6$ & 173.76 & 28.80 & $1,215.9$ & NA \\
\hline $23 \mathrm{H}-5$ & 182.18 & NA & $3,902.3$ & NA \\
\hline $24 \mathrm{H}-6$ & 192.93 & 2.68 & $4,024.2$ & NA \\
\hline $25 \mathrm{H}-2$ & 198.36 & NA & $8,401.4$ & NA \\
\hline $26 \mathrm{H}-2$ & 202.37 & 11.60 & $5,482.8$ & NA \\
\hline $27 \mathrm{H}-5$ & 215.79 & 53.20 & $5,086.3$ & NA \\
\hline $28 \mathrm{H}-3$ & 222.37 & 7.44 & $12,096.4$ & NA \\
\hline $29 X-5$ & 229.41 & 3.44 & $14,838.9$ & NA \\
\hline $30 X-7$ & 240.34 & 0.19 & $10,287.8$ & NA \\
\hline $31 X-6$ & 250.11 & 0.73 & $12,781.5$ & NA \\
\hline $32 X-7$ & 260.91 & 0.14 & $8,729.2$ & NA \\
\hline \multicolumn{5}{|l|}{ 316-C0008C- } \\
\hline $1 \mathrm{H}-2$ & 1.55 & 26.60 & $11,723.7$ & 1.4 \\
\hline $1 \mathrm{H}-5$ & 4.38 & 19.70 & $7,189.7$ & -17.6 \\
\hline $2 \mathrm{H}-2$ & 6.94 & 19.00 & $9,683.0$ & -18.8 \\
\hline $2 \mathrm{H}-7$ & 12.31 & 9.02 & $8,128.9$ & NA \\
\hline $3 \mathrm{H}-3$ & 17.85 & 4.34 & $10,103.9$ & 9.9 \\
\hline $3 \mathrm{H}-7$ & 22.05 & 0.94 & $8,532.5$ & NA \\
\hline $4 \mathrm{H}-5$ & 29.5 & 4.61 & $15,015.0$ & -4.8 \\
\hline $5 \mathrm{H}-5$ & 38.13 & 1.15 & $7,979.6$ & NA \\
\hline $6 \mathrm{H}-4$ & 47.88 & 0.73 & $7,502.2$ & -13.6 \\
\hline $7 \mathrm{H}-4$ & 55.99 & 3.54 & $3,664.6$ & NA \\
\hline $9 \mathrm{H}-4$ & 70.82 & 38.20 & 990.9 & -11.6 \\
\hline $9 \mathrm{H}-7$ & 73.14 & 61.30 & $2,449.5$ & NA \\
\hline $11 \mathrm{H}-2$ & 82.91 & 0.59 & $4,868.2$ & NA \\
\hline $10 \mathrm{H}-9$ & 83.41 & 130.90 & $1,187.0$ & NA \\
\hline $10 \mathrm{H}-12$ & 85.51 & 0.19 & $5,180.8$ & -7.9 \\
\hline $11 \mathrm{H}-10$ & 88.22 & 116.60 & 616.6 & NA \\
\hline $13 \mathrm{H}-8$ & 94.99 & 55.90 & $1,191.7$ & -27.0 \\
\hline $13 \mathrm{H}-10$ & 95.98 & 0.21 & $8,012.1$ & NA \\
\hline $15 \mathrm{H}-2$ & 102.05 & 2.68 & $1,607.2$ & NA \\
\hline $14 \mathrm{H}-6$ & 102.82 & 0.75 & $5,339.8$ & -0.5 \\
\hline $15 \mathrm{H}-5$ & 103.44 & 1.41 & $10,149.5$ & 1.7 \\
\hline $16 \mathrm{H}-5$ & 112.46 & 686.00 & $2,591.7$ & NA \\
\hline $18 \mathrm{H}-6$ & 126.36 & 1.96 & $5,971.8$ & NA \\
\hline $21 \mathrm{H}-5$ & 134.55 & 80.00 & $6,031.5$ & -0.5 \\
\hline $22 X-5$ & 144.22 & 3.57 & $6,036.2$ & NA \\
\hline $23 X-2$ & 149.75 & 0.15 & $2,666.1$ & NA \\
\hline $23 X-4$ & 150.51 & 2.17 & $6,768.1$ & -8.5 \\
\hline $24 X-4$ & 161.17 & 0.51 & $13,706.5$ & NA \\
\hline $24 X-5$ & 161.43 & 1.53 & $10,664.8$ & -1.0 \\
\hline $25 X-2$ & 167.41 & 0.13 & $10,883.3$ & NA \\
\hline $25 X-9$ & 171.76 & 0.10 & $14,806.4$ & -1.0 \\
\hline
\end{tabular}

AVS $=$ acid volatile sulfide, $C R S=$ chromium reducible sulfur, VCDT $=$ Vienna Cañon Diablo Troilite. NA $=$ not analyzed 